\title{
ASPEK SOSIO POLITIS NASKAH DAN ARKEOLOGIS
}

\author{
HE RI SUNANDAR \\ E-mail :heririau@gmail.com \\ Fakultas Syariah dan IImu Hukum UIN Suska Riau \\ HUSNI THAMR IN \\ E-mail : husnithamrin023@gmail.com \\ PPs UIN Sultan Syarif Kasim Riau
}

\begin{abstract}
History can not be separated from several past events which have important values for human life. Historians often seek to associate these events with the reality of human life in the present. Reviewing the history, it usually deals with a study of historical sites itself, especially the historical sites of kingdoms or sultanates. Therefore, reviewing the history of Islamic Malay kingdom in Daik Lingga and Pulau Penyengat Indera Sakti are very closely related to the study of historical sites which still exist as historical witnesses. The studies on Malay manuscript sthat will be presented include: Malay manuscript which is the work of the individual/personal; Malay manuscript which is belonging to Malay sultanate in the heyday of Islamic Malay Sultanate, such as texts of laws, and others; and studies on the sites ofheritages. This study focuses on the historical heritage sites of Malay sultanate, which include: heritage in the form of traces of ancient Malay sultanate, worship places, such as mosque, and others, grave of the kings and the princes in Malay region of Riau, and also inscriptions and archaeological.
\end{abstract}

Keywords: History, Malay, manuscript, and archaeological.

\section{PENDAHULUAN}

Kerajaan Daik Lingga dan Pulau Penyengat yang penuh dengan peninggalan situs-situs sejarah Melayu lama, maka sudah menjadi suatu keniscayaan untuk melakukan kajian tentang sejarah dan sekaligus pemetaan terhadap situs-situs sejarah Melayu tersebut. Jika tidak dilakukan segera mungkin dikhawatirkan semua peninggalan itu akan hilang ditelan zaman dan sejarah yang masih dikenang oleh orang-orang tua akan hilang bersama meninggalnya generasi tua yang sudah sangat langka di jumpai di Daik Lingga dan Pulau Penyengat.

Kajian khusus mengenai kesultanan Melayu Daik Lingga dan Pulau Penyengat Indra Sakti selama ini masih kurang mendapat perhatian pemerintah pusat, lawaupun telah lahir dari kesultanan ini dua nama yang 
Heri Sunandar \& Husni Tamrin, Aspek Sosio Politis Naskah Dan Arkeologis

tidak asing laing yaitu pencipta gurindam dua belas Raja Ali Haji, dan seorang pahlawan nasional Raja Haji Fi Sabilillah.

Berdasarkan observasi sementara di lapangan, bahwa satu persatu orang-orang tua yang mengetahui sejarah kesultanan ini sudah meninggal dunia, dan banyak situs-situs sejarah yang belum dibukukan menjadi satu kajian yang komprehensip dan dapat dijadikan sebagai rujukan sejarah nasional. Oleh sebab itu kajian tentang sejarah kesultanan Melayu Daik Lingga dan Pulau Penyengat Indra Sakti merupakan suatu keniscayaan dan tidak dapat ditawar lagi.

Belum banyak ditemukan penelitian yang berkenaan tentang masalah ini. Kajian tentang sejarah, situs sejarah, naskah, budaya, adat, hukum adat, dan lain-lain yang berkenaan dengan Daik Lingga dan Pulau penyengat masih belum banyak dilakukan. Namun akhir-akhir ini, telah ada upaya yang dilakukan oleh Kementrian Agama RI, yang mengirimkan beberapa peneliti yang khusus mengadakan kajian tentang naskah di Daik Lingga dan juga Pulau Penyengat Indra Sakti.

Ada beberapa buku tentang sejarah Kerajan Daik Lingga dan situssitus sejarah di Pulau Penyengat yang diterbitkan oleh Pemerintah Kepulauan Riau beberapa tahun yang lalu. Namun kajian ini masih bersifat global. Sedangkan kajian sejarah tentang Daik Lingga masih terbatas jumlahnya. Buku-buku yang ada kebanyakan menceritakan kegemilangan kesultanan Riau Lingga di Pulau Penyengat Indera sakti serta karya-karya besar para pujangga yang masuk dalam Syusdiah club dan lebih khusus lagi karya pujangga dan juga ulama Raja Ali Haji.

Data-data berkenaan tentang Daik, Lingga, dan Pulau Penyengat Indra Sakti banyak juga ditemukan di berbagai media cetak dan elektronik. Terutama yang diungkapkan melalui saluran internet. Untuk itu perlu ada upaya yang lebih serius untuk membukukan menjadi satu buku yang dapat dijadikan rujukan dan acuan bagi generasi yang akan datang, setelah dikompirmasi lebih jelas kepada orang-orang tua yang masih hidup dan merupakan saksi sejarah tersebut.

Bagaimana sejarah kesultanan Melayu Daik Lingga dan Pulau Penyengat Indra Sakti baik sebalum berdirinya, kiprahnya setelah berdiri, masa kejayaan dan sebab-sebab kejatuhannya. Bagaiamana situs-situs sejarah kesultanan Melayu Daik Lingga dan Pulau Penyengat Indra Sakti yang masih ada, demikian pula makna serta sejarah yang terkandung di dalam situs-situs tersebut.Bagaimana nilai-nilai filosofis dan substansi yang terkadung di dalamnya. 
Al-Fikra: Jurnal IImiah Keislaman, Vol.14, No.2, Juli - Desember 2015

\section{Sejarah Kesultanan Lingga Riau}

Kesultanan Riau-Lingga adalah kerajaanlslam yang berpusat di Kepulauan Lingga yang merupakan pecahan dari Kesultanan Johor. Kesultanan Lingga Riau, ini didirikan di Lingga setelah Sultan Mahmud Shah III kalah melawan Belanda, dan gugurnya seorang pahlawan Raja Haji Fi Sabilillah. Karena letak pusat kerajaan pada waktu itu di hulu sungai Riau (daerah Kota Piring di batu VI-Tanjung Pinang) dimana letaknya berdekatan dengan Residen Belanda di Tanjung Pinang, maka baginda memutuskan untuk memindahkan pusat pemerintahannya jauh dari Tanjung Pinang, yaitu di Pulau Lingga (Daik).

Walaupun letaknya sudah berjauhan dari Tanjung Pinang, namun karena tekanan yang tertubi-tubi dari Belanjda, selanjutnya, Kesultanan ini dibentuk berdasarkan perjanjian antara Britania Raya dan Belanda pada tahun 1824 dengan Sultan Abdul Rahman Muadzam Syah sebagai sultan pertamanya. Kesultanan ini dihapuskan oleh pemerintah kolonial Belanda pada 3 Februari1911.

Wilayah Kesultanan Riau-Lingga mencakup provinsi Kepulauan Riau modern, tapi tidak termasuk provinsi Riau yang didominasi oleh Kesultanan Siak, yang sebelumnya sudah memisahkan diri dari Johor-Riau. Kesultanan ini memiliki peran penting dalam perkembangan bahasa Melayu ${ }^{1}$ hingga menjadi bentuknya sekarang sebagai bahasa Indonesia.

Pada masa kesultanan ini bahasa Melayu menjadi bahasa standar yang sejajar dengan bahasa-bahasa besar lain di dunia, yang kaya dengan susastra dan memiliki kamus ekabahasa. Tokoh besar di belakang perkembangan pesat bahasa Melayu ini adalah Raja Ali Haji, seorang pujangga dan sejarawan keturunan Melayu-Bugis.

(a). Awal Berdirinya Kesultanan Lingga-Riau

Awal sejarah kesultanan Lingga-Riau bermula dari munculnya kesultanan Lingga-Riau di Pulau Bintan, yaitu dengan diangkatnya Tengku Sulaiman menjadi sultan pada Kesultanan Riau Johor Riau. Beliau dilantik menjadi Sultan pada tanggal 4 Oktober 1722 dengan gelar Sultan Sulaiman Badrul Alam Syah, yang berkedudukan sebagai Yang Dipertuan Besar Pertama.

Pusat pemerintahan kesultanan pada saat pelantikan berkedudukan di Riau tepatnya di Sungai Carang (Hulu Riau-sekarang termasuk dalam wilayah Kota Tanjungpinang) sehingga sejak itu, penyebutan nama Kesultanan Johor Riau berganti nama menjadi Kesultanan Riau Johor Pahang Lingga.

Berdasarkan beberapa sumber sejarah dapat diketahui bahwa Sultan Sulaiman Badrul alamsyah (sebelum dilantik menjadi sultan di Kesultanan 
Heri Sunandar \& Husni Tamrin, Aspek Sosio Politis Naskah Dan Arkeologis

Riau Johor Pahang bernama Tengku Sulaiman) adalah anak dari Tun Abdul Jalil. Tun Abdul Jalil adalah Bendahara Kesultanan Johor Riau semenjak masa pemerintahan Sultan Ibrahim Syah (1677-1685). Pengganti Sultan Ibrahim Syah yaitu Sultan Mahmud Syah II meninggal dalam usia muda, 24 tahun. Wafatnya Sultan Mahmud syah II menyebabkan timbulnya kemelut di dalam kesultanan Melayu Johor Riau karena Sultan Mahmud Syah II tidak meninggalkan ahli waris sebagai penggantinya. Beliau tidak memiliki keturunan. Dengan demikian yang menjadi Sultan adalah Bendahara Tun Abdul Jalil yang bergelar Sultan Abdul jalil Riayat Syah IV. Naiknya Bendahara sebagai Sultan menyebabkan konflik intern di Kesultanan Johor Riau, yang menyebabkan munculnya Raja Kecil yang mengaku sebagai ahli waris Sultan Mahmud Syah II yang ingin merebut kembali tahta sultan. Raja kecil berhasil mengalahkan sultan Abdul Jalil Riayat Syah IV dan dilantik menjadiS ultan Kesultanan J ohor Riau dengan gelar sultan Abdul J alil Rahmat syah.

Pada tahun 1722, Tengku sulaiman (anak Bendahara Tun Abdul jalil) "bersekutu" dengan bangsawan Bugis (Opu-opu Bugis Lima Bersaudara) untuk merebut kembali kekuasaan Johor Riau atas Raja Kecil. Pada akhirnya, kemenangan ada pada pihak Tengku Sulaiman. Tengku Sulaiman kemudian dilantik menjadi Sultan pada tanggal 4 Oktober 1722 dengan gelar Sultan Sulaiman Badrul Alam Syah, yang berkedudukan sebagai Yang Dipertuan Besar Pertama. Sejak itu, penyebutan nama Kesultanan Johor Riau berganti nama menjadi Kesultanan Riau Johor Pahang Lingga. Bahkan, sejak itulah, kerajaan tersebut berkembang, walaupun di dalamnya terjadi juga campur tangan pihak Belanda untuk melakukan politik adu domba interen kerajaan.

Politik dan pemerintahan Kerajaan Riau-Lingga saat itu telah mencerminkan kehidupan multikultural. Tidak ada istilah pemerintahan harus di tangan putra daerah. Yang Dipertuan Besar yang merupakan sultan Melayu, memimpin berdampingan dengan Yang Dipertuan Muda Riau, yang tak lain adalah raja muda keturunan Bugis. Bahkan, Kerajaan Melayu mencapai masa jayanya pada masa bertakhtanya Sultan Mahmud III sebagai raja bersama dengan Raja Haji sebagai Yang Dipertuan Muda Riau selaku pengendali roda pemerintahan.

Setelah kekalahan Kerajaan Riau-Lingga dalam Perang Riau tahun 1784, Sultan Mahmud Shah III memindahkan pusat pemerintahannya ke Daik, Lingga. Di sana, Sultan Mahmud Shah III membangun pasar, masjid, dan benteng kota berupa parit. Hal ini beliau lakukan karena perseteruan dengan Belanda dan melihat situasi yang kurang menguntungkan waktu itu, sehingga Sultan Mahmud akhirnya memutuskan untuk memindahkan pusat kerajaan ke Pulau Lingga.

Perpindahan secara total itu terjadi pada pertengahan tahun $1787 \mathrm{M}$. dimana sultan Mahmud berangkat dalam satu rombongan tak kurang dari 
Al-Fikra: Jurnal IImiah Keislaman, Vol.14, No.2, Juli - Desember 2015

200 perahu ke Lingga. Sedangkan 150 perahu lainnya dipimpin Temenggung Abdul Jamal pindah ke Pulau Bulang (sekitar Batam) dan menetap di sana. Hulu Sungai Riau menjadi kosong, hanya tinggal orang-orang Cina pemasak dan pekebun gambir yang kemudiannya menguasai ladang gambir yang ada.

Selanjuntnya, Kesultanan Riau Lingga merupakan kesultanan Islam yang terletak di Kepulauan Lingga yang merupakan pecahan dari Kesultanan Johor. Kesultanan ini dibentuk berdasarkan perjanjian antara Britania Rayadan Belanda pada tahun 1824 dengan Sultan Abdul Rahman Muadzam Syah sebagai sultan pertamanya. Kesultanan ini dihapuskan oleh pemerintah kolonial Belanda pada 3 Februari 1911. Wilayah Kesultanan Riau-Lingga mencakup provinsi Kepulauan Riau modern, tapi tidak termasuk provinsi Riau yang didominasi oleh Kesultanan Siak, yang sebelumnya sudah memisahkan diri dari Johor-Riau.

Kesultanan ini memiliki peran penting dalam perkembangan bahasa Melayu hingga menjadi bentuknya sekarang sebagai bahasa Indonesia. Pada masa kesultanan ini bahasa Melayu menjadi bahasa standar yang sejajar dengan bahasa-bahasa besar lain di dunia, yang kaya dengan susastra dan memiliki kamus ekabahasa. Tokoh besar di belakang perkembangan pusat bahasa Melayu ini adalah Raja Ali Haji, seorang pujangga dan sejarawan keturunan Melayu-Bugis.

Riau-Lingga pada awalnya merupakan bagian dari Kesultanan Malaka, dan kemudian Kesultanan Johor RiauPada 1811Sultan Mahmud Syah III mangkat. Ketika itu, putra tertua, Tengku Hussain sedang melangsungkan pernikahan di Pahang. Menurut adat Istana, seseorang pangeran raja hanya bisa menjadi Sultan sekiranya dia berada di samping Sultan ketika mangkat. Dalam sengketa yang timbul Britania mendukung putra tertua, Husain, sedangkan Belanda mendukung adik tirinya, Abdul Rahman. Traktat London pada 1824 membagi Kesultanan Johor menjadi dua: Johor berada di bawah pengaruh Britania sedangkan Riau-Lingga berada di dalam pengaruh Belanda. Abdul Rahman ditabalkan menjadi raja Riau-Lingga dengan gelar Sultan Abdul Rahman Muadzam Syah, dan berkedudukan di Kepulauan Lingga.

Sultan Hussain yang didukung Britania pada awalnya beribukota di Singapura, namun kemudian anaknya Sultan Ali menyerahkan kekuasaan kepada Tumenggung Johor, yang kemudian mendirikan kesultanan Johor modern.

Pada tanggal 7 Oktober 1857 Pemerintah Hinda-Belanda memakzulkan Sultan Mahmud IV dari tahtanya. Pada saat itu Sultan sedang berada di Singapura. Sebagai penggantinya diangkat pamannya, yang menjadi raja dengan gelar Sultan Sulaiman II Badarul Alam Syah. Selanjutnya, Jabatan raja muda (Yang Dipertuan Muda) yang biasanya dipegang oleh bangsawan keturunan Bugis disatukan dengan jabatan raja oleh Sultan Abdul Rahman II Muadzam Syah pada 1899. Karena tidak ingin menandatangani kontrak yang 
Heri Sunandar \& Husni Tamrin, Aspek Sosio Politis Naskah Dan Arkeologis

membatasi kekuasaannya Sultan Abdul Rahman II meninggalkan Pulau Penyengat dan hijrah ke Singapura. Pemerintah Hindia Belanda memakzulkan Sultan Abdul Rahman II in absentia 3 Februari 1911, dan resmi memerintah langsung pada tahun 1913.

Hal ini dapat dilihat dalam surat yang dikirimkan Belanda ke sultan Lingga Riau yang terakhir sebagai berikut:

Dengan nama Jang Dipertuan Besar Governeur General Betawi dichabarkan: Maka adalah Seri Paduka Governement Hindia Nederland menimbang fardu ini hari Djuga Seri Paduka Tuan Sultan Abdurrahman Muadzam Shah dan Tengku Umar (Tengku Besar) Kerajaan Riau Lingga sarta daerah takluknya diberhentikan dari pada pangkatnya itu.

Maka Tuan Sultan diberhentikan dari pangkatnya itu sebab banyak kali melanggar Politik Contract, beberapa kali djuga diberi nasihat oleh Seri Paduka Guberneur General Betawi dan Paduka Tuan Resident Tanjung Pinang Maka itu dengan tiada Tuan Sultan mengindahkan atau mengingatkan perjanjian yang akan mengubah apa-apa Jang tiada patut itu. Dan tiada sekali-kali akan melanggar Politik Contract lagi dan menurut segala perintah dan aturan Seri Paduka Governement dan Wakilnya. Dan djuga Tuan Sulaiman hendaklah menjalankan dan mengaturkan bersama-sama Wakil Govedrnement pemerintah yang adil didalam Negerinya. Maka mungkirlah ia didalam

Perjanjiannya dan djuga melanggar aturan jang menentang pasal memakai bendera Belanda Maka Tengku Umardiberhentikan dari pangkatnya itu sebab sama sekali ianya Mengikutkan orang jang berniat bermusuhan dengan Seri Paduka Governement Hindia Belanda dan ia mencucuk (menghasut)

Sampai Ayahandanya tiada mengindahkan sekalian nasihat Wakil Seri Paduka Governement itu. Maka karena itu Tuan Sultan djuga sama sekali mengikutkan orang jang berniat kejahatan itu. Maka mengikut pasal 6 ajat 4 pada Politik Contract tahun 1905 maka ketiadaan Sultan maka pemerintahan itu dipegang oleh kita Seri Paduka Tuan Besar Resident Riau dengan daerah takluknya sekalian.

Maka sekarang segala Kepala-kepala dan Bumi Putera dari Kerajaan Riau Lingga Dengan Daerah Takluannya. sekalian hendaklah mengaku dengan sesungguhnya akan Menjunjung dan Menghormati dengan Taatnya.

\footnotetext{
${ }^{2}$ Tengku Husein Saleh, dkk., Mengenal dan Mengenang Kebesaran Kerajaan Lingga Riau Sebagai Pusat Kebudayaan Melayu, Pemda Kabupaten Lingga, 2007, h. 65-66. Tengku Husein bin Tengku Saleh Penulis buku ini merupakan pewaris kesultanan Lingga Riau yang masih hidup, karena silsilah keterunannya bersambung sampai ke Sultan Mahmud III pendiri kesultanan Lingga Riau.
} 
Al-Fikra: Jurnal IImiah Keislaman, Vol.14, No.2, Juli - Desember 2015

Maka Seri Paduka Tuan Resident Riau Lingga dengan Daerah Takluannya sekalian jang memegang dengan Shah pangkat Sultandidalam Kerajaan ini.

Karna Perintahini akan dipegang dengan segala keadaan dan apa djuga dijalankan supaya Negeri-Negeri dibawah pemerintah kita ini bertambahtambah dengan keramaian dan kesentosaan, maka hendaklah KepalaKepala dan Bumi Putera menolong kita diatas pekerdjaan ini. Siapa-siapa Djuga jang akan Ingkar Pada Pemerintah Kita Akan Dihukum Dengan Hukuman J ang Patut Kadar Kesalahannya.

Surat ini termaktub di Penyengat pada 10 hari bulan Februari tahun 1911 M bersamaan 11 hari bulan Syafar 1329 Hijriyah. Kembali dari mandi syafar di Daik dengan kapal Seri Daik ke Penyengat untuk mengambil harta bendanya yang dapat dibawa lari Sultan Abdurrahman beserta keluarganya dan kerabatnya serta pengikut-pengikutnya berangkat melarikan diri ke Singapura. Adiknya bernama Raja Ali (1849-1927) Kelana melarikan diri ke Johor dan minta perlindungan kepada sultan Johor, kemudian ia diangkat menjadi mufti Johor.

Sultan Abdurrahman sebagai sultan terakhir menetap di Singapura sampai mangka di Singapura, 28 September 1930 dalam usia 79 tahun. Selama beliau memerintah Sultan Abdurrahman II berkududkan di DaikLingga tahun 1885-1900, dan di Penyengat 1900-1911.

Selama kesultanan Lingga Riau berdiri ada dua Sultan yang dipecat oleh Belanda, yaitu:

1). Sultan Mahmud IV Mudzaffar Shah, diturunkan pada tanggal 23 September 1857, dan melarikan diri meninggalkan Lingga, dan mangkat di Pahang pada 10 Juli 1864.

Sultan Abdurrahman II Muadzam Shah yang merupakan sultan lingga yang terakhir yang diturunkan pada tanggal 10 Februari 1911, dan melarikan diri ke Singapura, mangkat di Singapura tanggal 28 Desember 1930.

-nR a).Daftar sultan di Kesultanan Riau Lingga yang berpusat di Lingga (Daik) dan Penyengat Indera Sakti ${ }^{3}$.

\footnotetext{
${ }^{3}$ Ibid., h. 71-72.
} 
Heri Sunandar \& Husni Tamrin, Aspek Sosio Politis Naskah Dan Arkeologis

\begin{tabular}{|c|l|c|}
\hline No & N a m a & Masa Pemerintahan \\
\hline 1 & $\begin{array}{l}\text { Sultan Abdul Rahman Muadzam } \\
\text { Shah }\end{array}$ & $1818-1832$ \\
\hline 2 & $\begin{array}{l}\text { Sultan Muhammad II Muadzam } \\
\text { Shah }\end{array}$ & $1823-1835$ \\
\hline 3 & $\begin{array}{l}\text { Sultan Muhammad IV Muadzam } \\
\text { Shah }\end{array}$ & $1835-1857$ \\
\hline 4 & $\begin{array}{l}\text { Sultan Sulaiman II Badarul Alam } \\
\text { Shah }\end{array}$ & $1857-1883$ \\
\hline 5 & $\begin{array}{l}\text { Sultan Abdul Rahman II Muadzam } \\
\text { Shah }\end{array}$ \\
\hline
\end{tabular}

Nama yang diberikan sejak lahir adalah Hamidah. Beliau merupakan Anak perempuan pertama Raja Haji, Yang Dipertuan Muda Riau Lingga IV ( 1778-1784). Ibunya adalah Raja Perak, puteri Daeng Kamboja, Yang Dipertuan Muda Riau Lingga III (1748 -1777). Daeng Kamboja, adalah anak Daeng Parani, saudara tertua dari lima bersaudara para pendekar Bugis Luwu yang datang merantau ke semenanjung (Daeng Prerani, Daeng Marewa, Daeng Celak, Daeng Manambun, Daeng Kemasi). Raja Haji sendiri adalah anak Daeng Celak. Jadi kedua tokoh ini masih ada hubungan persepupuan. Perkawinan para keturunan bansawan Bugis-Melayu di era kerajaan Johor-Riau-Lingga itu (1722-1912) diatur dan direkayasa, untuk menjaga panca kaki garis keturunan dan kekuasaan. Ini salah satu strategi kesultanan Lingga Riau membangun kerjasama yang harmonis antara puak Melayu dan Bugis di kawasan Riau serantau.

Raja Hamidah adalah keturunan Melayu Bugis, generasi kedua. Generasi pertama adalah ayahnya, Raja Haji (anak Daeng Celak, Bugis asli dengan Tengku Mandak, Melayu asli). Karena itu mereka memakai gelar Raja. Raja Haji, keturunan Bugis-Melayu dan Raja Perak (anak Daeng Kamboja) keturunan Bugis Melayu. Raja Perak adalah isteri kedua dari Raja Haji. Isteri pertamanya adalah Tengku Lebar, anak Sultan Sulaiman Badrul Alamsyah, Sultan Johor-Riau yang I (1722-1760). Dari perkawinannya dengan isteri pertama ini, lahir Raja Djaafar, yang kemudian menjadi Yang Dipertuan Muda Riau Lingga ke VI (1805-1831).

Dalam catatan sejarah, belum ditemukan catatan yang pasti tentang tahun kelahiran Raja Hamidah. Ada sebuah sumber yang mencatat, Raja Hamidah lahir sekitar tahun 1766. Ini dikaitkan dengan usianya waktu meninggal, tahun 1849, sekitar 83 tahun. Tapi kalau dikaitkan dengan usianya saat menikah dengan Sultan Mahmud Lingga, tahun 1803, maka waktu itu berarti usianya sudah 37 tahun. Agak terlalu berumur untuk wanita Bugis atau Melayu ketika itu, yang sangat pantang menjadi gadis tua. Apalagi puteri seorang bangsawan kerajaan setingkat Yang Dipertuan Muda. Puteri- 
Al-Fikra: Jurnal IImiah Keislaman, Vol.14, No.2, Juli - Desember 2015

puteri mereka tidak jarang sudah dijodohkan ketika beranjak dewasa. Apalagi jika dikaitkan dengan catatan dari sumber tempatan Tuhfat An Nafis, dimana dikatakan bahwa Raja Hamidah meninggal sebulan setelah meninggalnya Yang Dipertuan Muda Riau- Lingga VII Raja Abdulrahman, yang dikatakan meninggal pada bulan Juni 1844. Ini berarti Raja Hamidah wafat tahun itu juga, dalam usia sekitar 70 tahun.

Dengan mencermati beberapa catatan lain dalam sejarah jatuh bangunnya kerajaan Riau Lingga, ada perkirakan Raja Hamidah lahir sekitar tahun 1773 atau 1774. Ini dikaitkan dengan catatan kepergiannya bersama abang sepupunya Raja Ali bin Daeng Kamboja yang kelak menjadi salah seorang Yang Dipertuan Muda Riau Lingga, saat selesai perang Riau tahun 1784, dimana dikatakan mereka telah menyingkir ke Siantan dan Sukadana (Kalbar).Saat itu dikatakan dia sebagai gadis sunti (usia gadis sunti itu biasanya antara 9 sampai 11 tahun). Perkiraan ini lebih mendekati, karena disamping saat dia menikah dengan Sultan Mahmud, usianya sekitar 29 tahun (lebih muda, dan dalam usia yang pantas untuk belum menikah ), juga usia itu lebih dekat dengan usia abangnya Raja Djaafar yang kemudian menjadi saalah seorang Yang Dipertuan Muda Riau-Lingga.

Sehubungan dengan itu, Saat berakhir perang Riau, Raja Djafar diperkirakan berusia 18 tahun, berati Raja Djaafar diperkirakan lahir tahun 1766, dan ketika dilantik jadi Yang Dipertuan Muda tahun 1805 usianya diperkira 40 tahun.

Adapun, tempat kelahiran Raja Hamidah menurut sumber tempatan, dikatakan di Ulu Riau, pusat pemerintahan kerajaan Riau Lingga, setelah pusat kerajaan itui (yang sebelumnya bernama Kerajaan Johor-Riau) pindah dari Johor. Ketika dia dilahirkan, ayahnya, Raja Haji masih berstatus Kelana Jaya Putera, yaitu jabatan yang diberikan kepada calon Yang Dipertuan Muda. Tugasnya menjaga teluk rantau, dan memerangi musuh yang datang. Raja Hamidah mungkin dilahirkan di Istana Kota Piring, karena ayahnya sudah membangun istana yang megah itu (letaknya di pulau Beram Dewa, di muara Sungai Riau), jauh sebelum dia menjadi Yang Dipertuan Muda. Tetapi mungkin juga di kawasan istana Yang Dipertuan Besar di Ulu Riau, karena di kawasan itu dahulunya baik Yang Dipertuan Besar (sultan ), maupun Yang Dipertuan Muda, menetap bersama, meskipun di istana yang berbeda. Catatan yang ada menunjukkan hanya adiknya, Raja Ahmad, yang dipastikan lahir di Istana Kota Piring itu, 1778.

Raja Hamidah masih punya beberapa saudara yang lain. Yang seibu dan seayah, adalah Raja Siti. Seayah berlainan ibu, antara lain Raja Djafaar, Raja Idris, dan tentu saja Raja Ahmad, si bungsu.

Sebagai puteri seorang Panglima perang, Kelana Jaya Putera, Yang Dipertuan Muda, maka Raja Hamidah tentulah dibesarkan dalam tradisi istana, tradisi kebangsawanan, tradisi perang dan meliterisasi. Tetapi, Raja Haji juga seorang yang sangat taat beragama, menghargai para ulama, dan 
Heri Sunandar \& Husni Tamrin, Aspek Sosio Politis Naskah Dan Arkeologis

ke istananya di Kota Piring, dia telah mendatangkan banyak guru dan ulama, dan mereka mengajar ilmu-ilmu, baik agama Islam, maupun ilmu pengetahuan lainnya, teremasuk tulis baca huruf Jawi kepada keluarga istana, termasuk Raja Hamidah dan saudara-saudaranya, dan para pembesar negeri. Kecuali itu, Raja Hamidah pun dibesarkan dalam tradisi adat yang kuat, baik tradisi adat Melayu melalui maupun Bugis. Tradisi ini tentu ikut membentuk karakter dan pemahaman Raja Hamidah tentang dirinya, posisinya sebagai puteri bangsawan, sebagai ahli waris dari seorang Yang Dipertuan Muda, dan garis keturunan yang unggul, baik dari garis Melayu maupun Bugis.

Proses pendidikan itu berlangsung di Dalam Besar (istilah yang dipakai untuk salah satu bagian utama di dalam istana ) Yang Dipertuan Muda, dan diawasi dengan ketat. Lalu, Raja Hamidah pun ketika menjelang dewasa ikut mengembara di tengah perang bersama abangnya Raja Djaafar, abang sepupunya Raja Ali, ibu tirinya Ratu Mas, dan keluarganya yang lain. Menyaksikan konflik politik yang mewarnai masa mudanya, yang akhirnya tentulah ikut mewujudkan sosok Raja Hamidah yang anggun, kukuh, beradat istiadat, cerdas, dan berpengetahuan.

Raja Hamidah mulai masuk ke wilayah kekuasaan dan politik begitu dia dewasa, dan kemudian dipersunting Sultan Mahmud III dan menjadi permaisuri kerajaan Riau Lingga. Saat menikah dengan Sultan Mahmud tahun 1803, Raja Hamidah memang sudah menjadi seorang perempuan yang matang, dan karena itu dinilai sanggup memikul berbagai masalah pelik bagi seorang perempuan istana, baik beban politik maupun tekanan kekuasaan lain dipundaknya, yang dititipkan para pemuka adat dan pembesar negeri, khususnya keturunan Bugis. Setelah menjadi permaisuri, dia bergelar Engku Puteri.

Dari sumber-sumber yang ada, dapat diketahui, bahwa Raja Hamidah adalah seorang permaisuri yang begitu setia mendampingi sang Sultan sebagai permaisuri yang gahara sampai Mahmud mangkat (1812). Bukan hanya sebagai permaisuri, tetapi juga seorang penasehat dan pemegang teraju adat dan tradisi dan menjalankan tugasnya sebagai Pemegang Regelia Kerajaan. Wanita Ranggi, peri sejarah ini, meninggal 5 Agustus 1844, di istananya, di pulau Penyengat. Jika benarlah dia lahir sekitar tahun 1774, maka saat meninggal, wanita perkasa dan berhati baja ini, berusia sekitar 70 tahun. Dia memang hidup lebih lama dibanding sang abangnya Raja Djaafar, Yang Dipertuan Muda Riau Lingga, yang meninggal tahun 1831, yang saat meninggal diperkirakan berusia 66 tahun. Keduanya meninggal dengan memendam rasa pedih dan kecewa atas takdir politik, meski keduanya merasa, telah mengemban tugas dipundak masing-masing dengan sekuat rasa. Mereka harus memendam luka persaudaraan yang lama dan berdarah. Sepak terjangnya sebagai permaisuri, sebagai ibu suri, sebagai pemegang regelia kerajaan, telah membuat namanya ditulis dan dicatat dalam berbagai 
Al-Fikra: Jurnal IImiah Keislaman, Vol.14, No.2, Juli - Desember 2015

buku kronik dan sejarah. Orang mengaguminya sebagai perempuan yang tegar, keras, dan tak kenal menyerah atas prinsip hidup dan amanah yang dilimpahkan padanya, dan juga seorang permaisuri yang kesepian.

Perkawinannya dengan Sultan Mahmud, memang sebuah perkawinan politik, bukan perkawinan yang bangkit dari rasa cinta. Ketika perkawinan itu terjadi, mereka berselisih usia 20 tahun lebih. Sultan Mahmud mendekati umur 50 tahun, dan sudah punya tiga isteri. Yang pertama, Engku Puan, puteri Bendahara Pahang, yang dianggap sebagai permaisuri gahara. Yang kedua, Encik Makoh, keturunan Bugis dan yang ketiga Encik Mariam, keturunan Melayu. Tapi Raja Hamidah telah menerima pernikahan itu dan ikhlas menjadi isteri keempat, dan dari penafsiran catatan-catatan yang ada, tampaknya dia sadar, saat menjalani perkawinan itu, paling tidak mengemban tiga tugas berat:

Dengan ikhlas harus melaksanakan nikah al-siasah (perkawinan politik) Pernikahan Raja Mahidah dengan Sultan Mahmud bertujuan untuk meredam konflik politik antara pihak Melayu dan Bugis, yang sudah lama bagai api dalam sekam. Mulai dari perseteruan Daeng Kamboja dengan Tun Dalam Terengganu, sampai akhirnya bermuara pada perebutan kekuasaan dan jabatan Yang Dipertuan Muda Riau Lingga antara Tengku Muda Muhammad (Putera Temenggung Abdul Jamal) dengan Raja Ali (putera Daeng Kamboja). Konflik politik yang diwarnai perang saudara ini, berlangsung lebih dari 8 tahun $(1795$ - 1803) dan menelan banyak harta dan nyawa.

Tengku Muda Muhammad melawan karena merasa dialah berhak sebagai Yang Dipertuan Muda, karena dialah yang ditugaskan dan diangkat oleh Sultan Mahmud sebagai Raja Muda (sebutan jabatan itu dari pihak Melayu sedangkan pihak Bugis menyebutnya Yang Dipertuan Muda), setelah Belanda yang menang perang melawan Riaun (1784) sebagaimana isi perjanjian diatas kapal perang Utrecht mensyarakatkan, bahwa jabatan Raja Muda (Yang Dipertuan Muda) tidak boleh diberikan kepada keturunan Bugis. Sementara Raja Ali, juga merasa berhak, karena jabatan Yang Dipertuan Muda itu hak keturunan Bugis dan sudah diikrarkan dalam Sumpah Setia Melayu-Bugis, sejak tahun 1722, dan dia katanya sudah dilantik menjadi Yang Dipertuan Muda Riau Lingga oleh Sultan Salahuddin Selangor, saudara Raja Haji, setelah Raja Haji tewas di Teluk Ketapang.

Inilah sengketa politik yang unik. Raja Ali itu, anak Daeng Kamboja, cucu Daeng Perani. Sementara Tengku Muda Muhamamad itu, anak Raja Maimunah dan Raja Maimunah ini, adalah anak Daeng Perani. Jadi yang berkelahi dan berebut kuasa itu, adalah cucu-cucunya Upu Daeng Perani. Satu mewakili dinasti Bugis Luwu, yang satu mewakili dinasti Melayu Johor. Tapi di darah kedua kaum itu sudah bercampur baur. Konflik ini memang benar-benar konflik kepentingan dan nafsu politik mereka. Karena itu, penulis lebih suka menulis urutan jabatan Yang Dipertuan Muda Riau Lingga setelah 
Heri Sunandar \& Husni Tamrin, Aspek Sosio Politis Naskah Dan Arkeologis

gugurnya Raja Haji, Yang Dipertuan Muda IV Riau Lingga, tahun 1784, adalah : Tengku Muda Muhammad, Yang Dipertuan Muda Riau Lingga V (1795- 1803), Raja Ali, Yang Dipertuan Muda Riau Lingga VI (1803-1805), Raja Djaafar Yang Dipertuan Muda Riau Lingga VII (1805-1832), dan Raja Abdulrahman, Yang Dipertuan Muda Riau Lingga VIII (1833-1844) dan seterusnya).

Untuk meredam konflik ini, maka harus ada perdamaian dan penyelesaian politik yang menguntung kedua pihak. Dan orang dibalik sekenario politik, dan perdamaian ini, berdirilah Sultan Salahuddin atau Raja Lumu, Sultan Selangor (Anak Daeng Celak, saudara kandung Raja Haji Fisabilillah, ayah saudara sepupu kedua tokoh yang bertikai itu). Raja Lumu ini, dalam perjalanan sejarah Riau Lingga memang menjadi tokoh sentral pihak Bugis, yang sangat disegani dan dihormati para keturunan Bugis. Namun tentu saja yang sangat tidak disenangi pihak Melayu, seperti Temenggung Johor, Bendahara Pahang, dan tokoh sentralnya pihak Melayu ini adalah Tun Dalam, Raja Terengganu.

Upaya damai itu, akhirnya melahirkan apa yang disebut sebagai Perdamaian Kuala Bulang (mengambil nama sebuah pulau besar di sekitar Batam, tempat menetap pihak keturunan Melayu, seperti Temenggung Johor dan Bendahara Pahang ), September 1803. Inti kesepakatan politik itu, antara lain adalah : Sultan Mahmud, sebagai sosok keturunan Melayu yang berkuasa akan mengawini Raja Hamidah (sosok keturunan Bugis, dan penerus Raja Haji Fisabilillah), dengan tujuan meluluhkan perseteruan Melayu dan Bugis. Bukan hanya dalam politik, juga dalam kehidupan seharihari. Dalam bayangan mereka, melalaui percampuran darah itu kelak, jika ditakdirkan, putera yang lahir dari perkawinan ini, akan menjadi putera mahkota ( Tengku Besar, begitu sebutannya ) sebagai calon sultan yang gahara, dan ditubuhnya darah Melayu dan Bugis bersatu, dan akan menjadi keturunan Bugis Melayu pertama di tahta kerajaan Riau Lingga (karena sebelumnya semua Sultan Johor, Riau, Lingga, harus berdarah Melayu yang sangat kuat, karena jabatan Sultan itu memang menjadi haknya orang-orang keturunan Melayu). Itulah beban politik dan sejarah yang diletakkan dibahu Raja Hamidah, perempuan bangsawan yang berusia 29 tahun itu.

Sementara itu, untuk mengeleminir konflik lainnya, anak Tengku Muda yang bernama Tengku Puan atau Tengku Buntat (neneknya adalah Raja Maimunah, anak Daeng Perani ), dikawinkan dengan putera sulung Sultan Mahmud, yang bernama Tengku Husin atau Tengku Long (ibunya Encik Makoh, keturunan Bugis, tetapi bukan permaisuri yang gahara ). Inipun sekenario penyelasaian konflik melalui percampuran darah. Kelak, putera Tengku Husin dan Tengku Buntat, diharapkan akan menjadi Sultan Riau Lingga dari campuran darah Bugis Melayu yang sudah sulit dibedakan.

Seterusnya, Raja Ali, tokoh Bugis itu, mendapat kembali jabatan Yang Dipertuan Muda, dan dia akan menjadi Yang Dipertuan Muda VI Riau-Lingga. 
Al-Fikra: Jurnal IImiah Keislaman, Vol.14, No.2, Juli - Desember 2015

Sedang Tengku Muda Muhammad, tokoh Melayu itu (saya menyebutnya Yang Dipertuan Muda Riau Lingga V) yang meskipun anaknya menjadi calon permaisuri kerajaan Riau Lingga, tapi dia menolak ketika ditawarkan jabatan jadi Temenggung Johor mengganti ayahnya Temenggung Abdul Jamal yang meninggal. Tengku Muda Muhammad memilih menyingkir ke Temasek (Singapura sekarang) dan kemudian menetap di pulau Bulang, meninggal di sana. Jabatan Temenggung, diberikannya kepada anak saudaranya Tun Abdurrahman.

Raja Hamidah sebagai permaisuri diharapkan dapat menjaga kepentingan pihak Bugis di puncak kekuasaan .Sebagai puteri bangsawan yang darah Bugis nya lebih besar, dapat diperkirakan, pihak pembesar Bugis, ingin Raja Hamidah sebagai permaisuri dapat menjaga kepentingan pihak Bugis di puncak kekuasaan. Baik dalam mengatur jabatan, maupun kepentingan ekonomi dan kekuasaan lainnya ( dalam Tuhfat An Nafis, ada kutipan kata bersayap yang diucapkan oleh Raja Ali, ketika Raja Hamidah hendak dikawinkan dengan Sultan Mahmud: Akhirnya hinggap juga elang itu ke sarang). Raja Hamidah diharapkan menjadi kekuatan di belakang layar yang ikut mengatur percaturan kekuaasaan yang menguntungkan pihak Bugis, sampai kepada penetapan siapa pengganti Mahmud kelak sebagai sultan, jika mahmud mangkat. Karena itu, masuk akal lah kalau Tengku Husin, disebut-sebut sebagai pilihan utama untuk dijadikan pengganti Mahmud, jika perkawinan Mahmud dan Raja Hamidah tidak menghasilkan keturunan (malangnya, memang begitulah takdirnya, meskipun menurut satu catatan Raja Hamidah sempat melahirkan seorang puteri, namun meninggal ), karena selain darah bugisnya lebih besar, dia juga putera yang sulung. Bukan Tengku Abdurrahman, putra mahkota kedua Sultan yang darah Melayunya lebih besar, karena ibu nya Encik Mariam adalah keturunan Melayu, dan juga bukan putera dari permaisuri gahara. Itulah beban yang agaknya dipanggul Raja Hamidah, yang setelah menjadi permaisuri.

Beberapa catatan yang menyatakan Raja Hamidah memang sangat menyayangi dan memanjakan Tengku Husin, anak tirinya itu. Memang tidaklah ada kutipan atau fakta eksplisit yang menyebutkan itulah memang perujudan dari beban politik yang dipikulkan oleh petinggi pihak Bugis kepadanya, dan Engku Puteri telah menjalankkannya sebagai strategi, dan itulah pula sebab mengapa ketika Raja Djaafar memilih Tengku Abdyrrahman sebagai pengganti Mahmudsyah, dan bukan Tengku Husin, maka Engku Puteri begitu marah, dan nyaris berpatah arang dengan saudara kandungnya itu.

Namun, dari berbagai catatan lain, sebuah kenyataan yang juga tercatat dengan baik adalah, ternyata Raja Hamidah telah meletakkan dirinya, benar-benar sebagai permaisuri dan isteri yang setia, dan bukan sebagai personifikasi kepentingan politik keturunan Bugis semata. Dia benarbenar sebagai seorang isteri, seorang permaisuri, tempat Sultan Mahmud 
Heri Sunandar \& Husni Tamrin, Aspek Sosio Politis Naskah Dan Arkeologis

meletakkan kasih sayang dan kerinduannya. Tempat Sultan bertanya, tempat sultan mencurahkan kerisauannya. Kecantikannya, kecerdasannya, keteguhan hati, dan pemahamannya yang luas tentang politik, adat istiadat dan kebiasaan negeri-negeri yang besar (Engku Puteri banyak belajar dari pamannya Sultan Selangor tentang pemerintahan, dan belajar membangun negeri dengan sering berkunjung ke Selangor, Malaka, dll di semenanjung Malaka ) membuat pengetahuannya sangat luas, dan arif dalam bersikap.

Engku Puteri telah menjadi Think Tank nya Sultan Mahmud. Menjadi penasehat (bukan pembisik ), dan pengawal adat istidat dan budaya kerajaan Melayu itu. Karena itu pulalah agaknya, kemudian Sultan Mahmud, memberi dia tugas menjadi penjaga dan pemegang Regelia Kerajaan, lambang kedaulatan dan kuasa negeri (sebuah perangkat sakral kerajaan, berupa tanda dan panji keberasaran, perangkat nobat, Sirih Besar (cogan, gendang, nafiri, dlI). Perangkat kebesaran ini adalah supremasi tertinggi bagi eksistensi sebuah kekuasaan, sebuah negeri, sebuah kedaulatan tidak akan sah dan berdaulat seorang Sultan, jika pelantikannya tidak menggunakan Regelia ini. Karena itu Pemegang Regelia itu, sekaligus juga adalah penjaga adat istidat, dan tradisi . Di dalam kesatuan antara Regelia dan adat kebesaran budaya kerajaan itu, melekat marwah (kehormatan), harkat dan martabat kerajaan . Jika rusak dan binasa kedua kekuatan spritual ini, maka hancur dan runtuhlah harkat dan harga diri bangsa itu. Bagi Kerajaan-kerajaan Melayu di rantau itu, sebuah kerajaan boleh saja ditakluk, direbut, dan dikuasai oleh pihak lain. Raja atau Sultannya bisa saja terusir dan melarikan diri ke kawasan lain, mencari perlindungan. Tetapi, selagi Regelia Kerajaan tidak dirampas, tidak direbut, selagi Regelia sakti dan keramat itu masih dipegang sang rajanya, maka selagi itulah kedaulatan negeri itu masih tegak. Sultannya tetap punya daulat, dan dia bisa berkerajaan dimana saja, dan dirajakan dimana saja.Karena sukma yang sakti itu, belum ditaklukkan. Karena itulah, siapapun yang memegang dan diberi tugas menjaga Regelia itu, adalah seorang yang kuat dan perkasa. Seorang yang kuasanya jauh diatas kekuasaan lain, termasuk sultannya sendiri.

Raja Hamidah diharapkan menjadi sosok yang menjadi simbol dari eksistensi keturunan Bugis yang ada di Riau dan tempat kaumnya berlindung dan hidup terjaga di negeri tanah melayu. Sebagai keponakan Sultan Selangor (Raja Lumu), Raja Hamidah diharapkan menjadi sosok yang menjadi simbol dari eksistensi keturunan Bugis yang ada di Riau, tempat kaumnya berlindung dan hidup terjaga di negeri orang. Sebagaimana beban yang dipanggul pamannya itu untuk keturunan Bugis yang ada di Semenanjung. Ini beban yang tak kurang beratnya. Apalagi, begitu selesai pesta perkawinannya dengan Sultan Mahmud, maka sang Sultan telah memaklumkan bahwa dia menganugerahkan Raja Hamidah, sebuah pulau, yaitu pulau Penyengat Inderasaksi, sebagai maskawin dan tempat kediaman, tempat istana permaisuri. Dengan penganugerahan itu, maka Mahmud juga 
Al-Fikra: Jurnal IImiah Keislaman, Vol.14, No.2, Juli - Desember 2015

memaklumkan, bahwa sejak hari itu dia membagi wilayah kuasa ekonomi antara pihak Melayu dan Bugis.

Raja Hamidah, dengan para saudara-saudara dan pihak bugis lainnya, akan memiliki pulau penyengat dan kawasan sekitarnya (sampai ke Batam, Natuna, dan sekitarnya) sebagai " daerah permakanan ". Sumber ekonomi, pendapatan, dan biaya hidup mereka, dan pihak Melayu tidak boleh mengganggu gugat. Karena itulah kelak di pulau Penyengat itu pulalah, misalnya, Yang Dipertuan Muda Riau Lingga, sebagai sosok Bugis dan kuasanya, akan beristana dan mengendalikan pemeritahan, serperti yang dilakukan Raja Djaafar, seperti urusan pertahanan, ekonomi, politilk dan hubungan luar negeri .

Sedangkan Lingga (Daik dan sekitarnya, termasuk Singkep, dll ) menjadi kawasan " permakanan " pihak Melayu, melalui sosok Tengku Abdurrahman (tampaknya, memang sejak awal Sultan mahmud telah menetapkan penggantinya, adalah Tengku Abdurrahman atau si Komeng atau Tengku Jumat), putera kedua Sultan Mahmud, dan pihak Bugis tidak boleh mengganggunya (di Singkep ketika itu sudah ditemukan dan diproduksi timah). Beberapa penulis sejarah tentang jatuh bangun keraajaan Melayu Riau Lingga, kemudia menganggap keputusan Sultan Mahmud membagi wilayah permakanan ini sebagai keputusan poilitik yang luar biasa dampak dan pengaruhnya dikemudian hari bagi kedua kaum itu dan kerajaan itu sendiri. Dan sebagai salah satu strategi untuk mengakhiri konflik politik di kerajaan Riau-Lingga.

Engku Puteri memang gagal menjadi permaisuri yang mewariskan putera mahkota dan membangun zuriat dari darahnya untuk menjadi Sultan di puncak kekuasaan Riau Lingga. la memang gagal merajakan anak tirinya Tengku Husin sebagai Sultan Riau. Tapi, dia berhasil menjadi benteng yang tangguh sebagai pemegang, pemelihara, dan pengawal kebesaran dan kedaulatan kerajaan, yang bernama Regelia itu. Dia berhasil menjadi kekuatan yang senantiasa menjaga kesucian Sirih Besar dan perangkat kebesaran dan lambang kekekuasaan itu, sebagai kekuatan suci dan semua yang di bawahnya harus tunduk dan berlutut. Itulah sebab mengapa dia rela berselisih paham, dan nyaris memutus hubungan darah dan persaudaraan dengan abangnya Raja Djaafar, Yang Dipertuan Muda Riau Lingga, ketika Raja Djaafar justru menetapkan Tengku Abdurrahman sebagai pengganti Sultan Mahmud yang mangkat, dan bukan memilih putera sulung Sultan, Tengku Husin. Engku puteri menentang pemilihan itu, dan menganggap penetapan Tengku Abdurrahman itu, melanggar adat dan kebiasaan, apalagi ketika itu Bendahara dan Temenggung, dua pejabat teras kerajaan tidak berada ditempat dan belum memberi persetujuan. Raja Djaafar dianggap melanggar tradisi dan menjatuhkan marwah Kerajaan Riau Lingga. Karena itu pula, dia tidak mau menyerahkan Regelia kerajaan itu ke tangan Tengku Abdurrahman sebagai simbol pelantikan. Dia membawa pusaka keramat itu 
Heri Sunandar \& Husni Tamrin, Aspek Sosio Politis Naskah Dan Arkeologis

ke istananya di Penyengat, dan membiarkan Raja Djaafar melantik Sultan Abdurrahman (1812) tanpa regelia. Membiarkan peristiwa pelantikan itu menjadi sebuah peristiwa sejarah yang sumbang dan memalukan. Dan membiarkan Sultan Abdurrahman merasa belumlah sebagai Sultan, dan membiarkan Raja Djaafar sang Yang Diperttuan Muda, berduka dan terluka.

Perseteruannya dengan abangnya itu, menjadi konflik baru Bugis Melayu yang formulasinya sudah makin sulit diterjemahkan. Konflik itu tidak lagi konflik darah dan keturunan, tetapi menjadi konflik kepentingan, kekuasaan, dan rasa ketidak puasan lainnya yang rawan untuk ditunggangi oleh tangan tanagan politik yang keji dan jahat. Begitu marahnya Engku Puteri kepada abangnya itu, membuat dia nyaris tidak pernah lagi menjejakkan kaki ke Lingga. Sementara Raja Djaafar pun, begitu kecewa pada adiknya, sehingga tidak lagi mau beristana di Penyengat, dan memilih tetap di Daik, Lingga. Perseteruan ini begitu melukakan (meskipun akhirnya Regelia itu berhasil diambil Sultan Abdurrahman dengan bantuan Belanda secara paksa, 1821) dan terus berdarah. Hanya, ketika datang kabar Raja Djaafar gering dan hampir naza, maka Engku Puteri akhirnya pergi juga ke Lingga. Dia memaafkan abangnya, agar abangnya dapat menghadapi maut dengan tenang dan tanpa beban. Raja Djaafar pun demikian, seakan hanya rela meninggalkan dunia fana itu setelah berdamai dengan adiknya (cerita ini dengan bagusnya ditulis oleh Raja Ahmad, adik bungsu mereka dalam Syair : Syair Engku Puteri pergi Ke Lingga ). Engku Puteri ingin membawa abangnya yang sedang sakit itu ke Penyengat, dan merawatnya, tetapi abangnya menolak. Akhinya, setelah melihat sakit abangnya berangsur pulih, dia pun kembali ke Penyengat. Tetapi, kesembuhan itu ternyata hanya permainan perasaan, untuk menyenangkan hati mereka yang ditinggalkan. Tak lama Raja Djaafar pun meninggal dengan tenang di Daik. Di kebumikan di sana, dan baru beberapa tahun kemudian, jenazahnya di bawa ke Penyengat dan dimakamkan di sana. Dan Engku Puteri, membawa luka itu yang secara tak terasa terus menggerogoti usianya. Kesedihan melihat perderitaan abangnya akibat sengketa itu, membuat Engku Puteri menjadi nelangsa sampai ke akhir hayatnya.

Keteguhan hati Engku Putri Hamidah dapat disaksikan dalam sejarah Kesultanan Melayu Lingga dan Menyengat Indera Sakti, sebagai berikut:

(1). Upaya Inggris mengadu domba puak Melayu dan Bugis di Keslutanan Melayu Riau Lingga. Ketika Inggris yang bertapak di Singapura, dibawah kendali Thomas Standford Raffles, dan tangan kananannya Mayor William Farquhar, mulai menjalankan politik kotornya untuk memecah belah kerajaan Riau Lingga. Mereka, memanipulasi perasaan kecewa Tengku Husin yang gagal menjadi Sultan Riau dan Kelompok Temenggung Johor yang merasa telah disingkirkan pihak Bugis, dengan cara mengangkat Tengku Husin sebagai Sultan Singapura. Untuk melantik Tengku Husin secara syah menurut adat istiadat Melayu sebagai Sultan, mereka berusaha untuk 
Al-Fikra: Jurnal IImiah Keislaman, Vol.14, No.2, Juli - Desember 2015

mendapatkan Regelia Kerajan Riau yang ada ditangan Engku Puteri, karena mereka tahu Regelia itu masih tetap ditangan Engku Puteri, dan belum direbut oleh lawan politik mereka, Belanda yang saat itu menguasai Riau Lingga dan sekitarnya. Mereka suruh Tengku Husin membujuk ibu tirinya Engku Puteri agar Regelia itu diserahkan kepadanya, karena dia akan dijadikan Inggris sebagai Sultan di Singapura. Mereka begitu yakin akan memperoleh benda pusaka itu, karena mereka tahu betapa sayangnya Engku Puteri pada Tengku Husin yang dulu dibelanya supaya menjadi Sultan Riau Lingga. Tapi, Engku Puteri ternyata menolak, karena menganggap tindakan anak tiri kesayangannyan itu, justru melanggar adat dan akan memecah belah kerajaan Riau. Raja Hamidah begitu kecewa atas prilaku anak tirinya itu.

Karena Tengku Husin gagal membujuk ibu tirinya, lalu mereka mencoba menyuap Engku Puteri dengan menawarkan sejumlah uang, sekitar 50.000 ringgit Spanyol, untuk menyerahkan Regelia itu. Engku Puteri tetap menolak, dan kali ini merasa sangat terhina oleh tawaran uang suap itu (Engku Puteri tak memerlukan uang itu, karena dia sendiri cukup kaya). Dia menganggap sikap arogan Raffles dan bawahannya Mayor Farquhar itu sebagai tindakan penjajahan dan mau merampas kedaulatan Riau melalui penguasaan Regelia kerajaan. Akhirnya, karena gagal memiliki Regelia itu, dan agar pelantikan Tengku Husin tetap bermakna secara adat, mereka sengaja mengantit (mencopot) perabung (bumbungan) istana Engku Puteri di Penyengat, dan dibawa ke Singapura, dan dijadikan simbol pelantikan. Tengku Husin akhirnya dilantik sebagai sultan Singapura oleh Inggeris (Februari 1819) dengan gelar Sultan Husin Muhammadsyah, dan sejak itu Kerajaan Riau Lingga yang kekuasaannya termasuk Johor Pahang dan Singapura, pecah dua. Riau Lingga dibawah Sultan Abdurrahman, dan Singapura, Johor dan Pahang dibawah Sultan Husin. Pemisahan itu menjadi lebih nyata sejak Traktat London, tahun 1824.

(2). Belanda ikut campur dalam komplik interen kesultanan Melayu Riau Lingga.

Belanda yang sudah bercokol kembali Di Riau Lingga setelah tahun 1815 (Perjanjian Wina) dan berbagi wilayah penjajahan dengan Inggris, mulai ikut campur dan membantu Sultan Abdurrahman untuk memiliki Regelia itu. Karena sejak dilantik jadi Sultan Riau Lingga (1812), Sultan Abdurrahman tetap belum merasa sebagai Sultan, meski sudah 10 tahun berkuasa, karena Regelia kerajaan itu belum dimilikinya. Karena itu, dia sempat merajuk dan meninggalkan Riau menuju Pahang, pertengahan 1822, dan mengancam tak akan kembali ke Lingga sebelum Regelia itu dimilikinya. Sultan memilih merajuk ke Pahang, meskipun sebenarnya dia dan Raja Djaafar dengan kekuasaannya bisa saja merampas Regelia itu dari tangan Engku Puteri yang tidak memiliki kekuasaan angkatan perang, serdadu dan senjata, namun mereka tetap tidak mau menggunakan kekerasan, dan merasa sangat kualat 
Heri Sunandar \& Husni Tamrin, Aspek Sosio Politis Naskah Dan Arkeologis

kalau sampai melakukan kekerasan. Mereka tahu, Regelia yang sakral dan sakti itu, akan kehilangan kuasa dan kesaksaralannya jika diambil dengan paksa, apalagi dengan darah.

Karena itu, pertengahan tahun 1822,setelah Sultan dan Yang Dipertuan Muda gagal membujuk Engku Puteri untuk menyerahkan secara sukarela regelia itu, maka Belanda, melalui Kapten Andrean Kock, memaksa Sultan dan Yang Dipertuan Muda, lalu mengirim utusan menghadap Gubernur Jendral Belanda, Gerard Philip Baron van der Capellen,di Batavia, untuk meminta bantuannya . Yang memimpin utusan itu, sengaja dipilih Raja Ahmad, adik Engku Puteri sendiri, untuk menunjukkan betapa kaum kerabat Engku Puteri di kerajaan Riau Lingga menentang sikap Engku Puteri yang enggan melepas Regelia itu. Lalu, orang lain yang dikirim ke Batavia adalah orang kepercayaan Raja Djaafar dan pelobi ulung, Sayed Zein al Qudsi.

Keputusan Belanda mengirim utusan itu, karena mereka sadar bahwa Inggeris bisa saja merebut Riau Lingga jika Sultan Abdurrahman yang merajuk ke Pahang itu, tiba-tiba berpaling tadah dan meminta Inggeris turun tangan, karena menganggap Belanda sendiri tidak mau membantunya. Karena itulah, maka Van der Capellen, lalu menugaskan Gubernur Belanda di Malaka, J.S.Timmermann Thijssen, agar dapat membantu membujuk Engku Pureri menyerahkan perangkat kebesaran adat itu, dengan cara mengundang Engku Puteri ke Malaka. Gubernur Jenderal Belanda di Batavia itu dikatakan juga telah mengirimkan sejumlah hadiah (seperti gramophone atau peti bernyanyi, kalung, benda benda kristal, dll ) melalui Gubernur Malaka, untuk melunakkan hati Engku Puteri. Tapi tawaran dan bujukan itu, meskipun diterima dan disimpan di istana Engku Puteri, tetapi janda Sultan Mahmud itu tetap menolak untuk menyerahkan Regelia kerajaan. Dia memberitahu Belanda bahwa Regelia Kerajaan Riau Lingga itu adalah kedaulatan sebuah negeri, dan Regelia itu hanya boleh dimiliki oleh sebuah kekuasan yang benar-benar menjunjung tinggi adat dan tradisi pemerintahan negeri Melayu.

Karena bujuk rayu tidak juga berhasil, akhirnya Timmerman Tijssen memutuskan menugaskan Andrean Kock agar mendapatkan secara paksa Regelia itu, dengan bantuan dari Graaf van Ranzow, Residen Belanda di Tanjungpinang dan pasukannya. Mereka lalu mengepung dan memaksa masuk ke istana Engku Puteri di Penyengat, dan memaksa Engku Puteri untuk menyerahkan Regelia itu. Bahkan, tak lama berselang, Gubernur Malaka Timmerman bersama sejumlah pasukan juga datang ke Penyengat. Dibawah todongan pistol, senapan dan ancaman kelewang (bahkan sebuah letusan pistol terdengar di istana itu ), mereka merampas Regelia itu dari tangan Engku Puteri. Perampasan itu terjadi di depan sejumlah pejabat tinggi kerajaan Riau Lingga. Engku Puteri diriwayatkan tetap melawan dengan cara mengecam prilaku tak terpuji Gubernur Malaka dan pasukannya itu, Regelia itu tetap dirampas secara paksa, dan perempuan berhati baja itu, yang ketika 
Al-Fikra: Jurnal IImiah Keislaman, Vol.14, No.2, Juli - Desember 2015

itu berusia hampir setengah abad, memang akhirnya tak berdaya mempertahankannya. Seakan dengan pekikan panjang, Engku Puteri telah memaklumkan kepada para serdadu dan Gubernur Malaka itu, bahwa Regelia yang sakral itu, telah kehilangan kesaktiannya, begitu dia diambil dengan paksa dan dirampas dari tangan orang yang telah menjaganya sepanjang usia. Kemarahannya itu, sangat terasa dalam salah satu bahagian dari suratnya kepada Gubernur Jenderal Van Der Capellen, Desember 1822 (tiga bulan setelah Regelia itu dirampas), sebagai protes cara-cara kasar yang dilakukan oleh Gubernur Malaka itu.

Jikapun dalam surat itu, Engku Puteri terkesan bicara dengan sopan dan hormat, namun itu, dapat ditafsirkan sebagai siasat, agar peristiwa perampasan dan perlawanannya kepada Belanda itu tidak berimbas kepada sanak saudaranya yang lain, khususnya adiknya Raja Ahmad. Engku Puteri ingin resiko perlawanan itu dia tanggung sendiri, karena itu adalah bahagian dari perjuangan dan perlawanannya menegakkan marwah kerajaan melayu Riau Lingga, dan menjalankan amanah dari sang suaminya Sultan Mahmud. Suatu pembangkangan yang tak kurang dari 10 tahun lamanya, semenjak Sultan Mahmud mangkat. Engku Puteri menyaksikan betapa menderitanya adiknya Raja Ahmad yang terpaksa harus menjalankan tugas yang serba salah itu. Dia tahu adiknya sempat jatuh sakit ,parah dan hampir maut, dalam perjalanan pulang dari Batavia menghadap Gubernur Jendral Belanda itu.

Regelia itu, dibawa ke kantor Residen Belanda di Tanjungpinang, dan disimpan disana. Kemudian, Sultan Abdurrahman pun pulang dari Pahang, setelah mendengar Regelia itu sudah jatuh ke tangan Belanda, dan akan diserahkan keapadanya. Dan November 1822, Sultan Abdurrtahman pun dikukuhkan sebagai Sultan Riau Lingga dengan Sirih Besar dan perangkat Regelia lainnya. Dalam catatan sejarah dikatakan, pelantikan itu berlangsung dengan sangat sumbang, dan menyimpang dari berbagai adat resam negeri Melayu. Sepuluh tahun kemudian Sultan Abdurrahman meninggal, setelah setahun sebelumnya didahului kepergian Yang Dipertuan Muda Raja Djaafar. Setelah kejadian itu, bala dan bencana nyaris terus menerus menimpa kerajaan Riau Lingga, dan silih berganti kejatuhan terjadi. Mulai dari kezaliman Belanda memakzulkan Sultan Riau Lingga, seperti Sultan Mahmud Muzaffarsyah, 1857 (setelah 17 tahun memerintah) dan Sultan Abdurrahman Muaazzamsyah, 1911 sultan terakhir Riau Lingga. Maka berakhirlah imperium Melayu ini, dengan sejumlah jejak sejarah yang gemilang, cemerlang, dan juga kepedihan.

Nama lingga sudah lama dikenal oleh orang Melayu dan para pedagang yang melintas di kepulauan riau. Sebagian cerita mengatakan bahwa nama lingga diberikan oleh pelaut China dimasa lalu. Dalam bahasa Tionghua, Ling artinya Naga dan Cie artinya gigi, karena mereka memandang puncak gunung daik yang kelihatan dari jauh menyerupai gigi 
Heri Sunandar \& Husni Tamrin, Aspek Sosio Politis Naskah Dan Arkeologis

naga. Hal ini kemungkinan ada benarnya karena orang-orang Tionghua lebih dahulu mendiami pulau Lingga ini.

Satu lagi pendapat mengatakan bahwa kata lingga berasal dari baru "Linggam" yaitu bahasa Hindustan atau Sanskrit, karena menurut sejarah zaman Sriwijaya yang berpusat di Palembang, Pulau Lingga termasuk salah satu jajahannya . "Linggam" dalam bahasa Hindu berarti tanah merah. Hal ini karena jika dilihat tanah gunungnya itu berwarna kemerah-merahan.

Peranan kesultanan melayu Riau Lingga ini sangat dirasakan dengan berperannya Rusydiah club yang menghasilnya banyak karya-karya anak negeri melayu. Tokoh utama dalam hal ini adalah Raja Ali Haji yang terkenal dengan karnyanya; gurindam dua belas.

Sebenarnya budaya tulis di kalangan para bangsawan melayu dan bugis baik dari keluarga tengku mamupun raja, sama-sama memiliki tradisi menulis sehingga hasil-hasil karya mereka masih dapat disaksikan sebagian besar sampai saat ini berupa manuskrip yang disimpan di rumah-rumah pribadi keturunan Yang dipertuan Muda atau raja dari keturunan bugis, maupun tengku dari keturunan sultan Riau Lingga.

Bahasa Melayu telah menjadi bahasa Lingua Franka atau bahasa pergaulan, karena bahasa Melayu mempunyai struktur kalimat yang mudah dimengerti dan mudah memiliki ejaan yang baik sehingga bahasa Melayu dijadikan bahasa nasional Indonesia. Kesultanan lingga memainkanperanan yang sangat penting terutama sekali dalam hal pengembangan bahasa Melayu secara lebih luas dalam media tulis dan sastra lisan bagi masyarakat luas, sehingga bahasa melayu mengambil peranan sebagai bahasa lingua pranca niaga yang dipakai di berbagai perdagangan di nusantara.

Dalam hal ini peranan Raja Ali Haji sangat besar untuk mengangkat bahasa Melayu lebih lusa dikenal. Berbagai karnya selain mengungkapkan berbagai kisah dan sejarah perjuangan kesultanan Lingga-Riau. Diantara karnya yang paling monumental adalah Gurindam dua belas, tuhfat an-Nafis, dan lain-lain. Tamadun (peradaban) yang sudah dikembangkan pada masa kegemilangan kesultanan Lingga Riau adalah percetakan uang logal yang digunakan sebagai mata uang dalam perdagangan selain mata uang belanda dan eropa lainnya. Hal ini dapat disaksikan pada musium Lingga yang tersimpan dengan rapi.

Adapun mengenai seni arsitekur, seni ukir, seni rupa dan lainnya, telah dikembangkan sejak pasa kesultanan ini masih berapa di Melaka yang kemudian pindah ke Johor, lalu pindah ke Lingga dan terakhir di Pulau Penyengat Indera Sakti. Semua tamadun tersebut dikembangkan sesuai dengan tuntutan zaman. Daik adalah sebuah kecamatan yang terletak di kabupaten Lingga provinsi Kepulauan Riau. Daik, dahulunya kurang lebih selama seratus tahun menjadi pusat kerajaan Riau-Lingga, sekarang menjadi ibu kota Kecamatan Lingga, Kabupaten Kepulauan Riau. Peta Lingga-Daik itu dapat dilihat pada gambar berikut ini: 
Al-Fikra: Jurnal IImiah Keislaman, Vol.14, No.2, Juli - Desember 2015

Kota Lingga-Daik yang terletak di sungai Daik, hanya dapat dilalui perahu atau kapal motor di waktu air pasang. Kalau air surut, sungai Daik mengering dan tak dapat dilalui. Perhubungan lainnya adalah melalui jalan darat ke desa Resun di sungai Resun. Dari sana melalui sungai itu terus ke muara (Pancur) yang terletak di pantai utara pulau Lingga, berseberangan dengan Senayang.

Sebelum kapal motor merapat ke pelabuhan Daik Lingga, para pengunjung dapat melihat gunung Daik yang bercabang 3.

Raja-raja kerajaan Riau-Lingga yang pernah memerintah kerajaan selama periode pusat kerajaan di Daik Lingga yaitu : Sultan Abdurakhman Syah (1812-1832), Sultan Muhammad Syah (1832-1841), Sultan Mahmud Muzafar Syah (1841-1857), Sultan Sulalman Badrul Alam Syah II (18571883) dan Sultan Abdurrakhman Muazzam Syah (1883-1911).

Di Benteng Kuala (Muara) Sungai Daik sekitar 2 km dari Kampung Cina di Daik-Lingga.Untuk mencapai lokasi ini dapat ditempuh dengan menggunakan sampan. Masyarakat menyebut tempat ini sebagai Tanjung Meriam, karena menurut informasi, di tempat tersebut dulu banyak ditemukan meriam. Sisa bangunan yang ada saat ini hanyalah susunan batu yang menjorok ke laut. Keletakan benteng ini sangat strategis, yaitu berada di pintu masuk ke pusat kota yang dapat dilalui dengan menggunakan kapal. Kerusakan benteng tersebut kemungkinan akibat gerusan air laut yang semakin tinggi pada saat pasang, akibat pengendapan Lumpur pada muara Sungai Daik.

Di Benteng ini terdapat meriam-meriamnya yang masih terbenam. Kuala Daik adalah lalu lintas sungai Daik yang dulunya dalam dan lebar, dapat dilewati kapal dagang Kerajaan sampai kekampung Lingga berdekatan dengan lokasi pabrik sagu Sultan Sulaiman Badrul Alamsyah.

c.Benteng Tanah di Pabean

Benteng tanah ini terletak di pusat Kota Kecamatan Lingga, di sebelah utara Kantor Kecamatan Lingga dan tidak jauh dari arah aliran Sungai Daik. Kondisinya saat ini tidak beraturan, hampir rata dengan tanah akibat aktivitas penduduk disekitarnya. Lebar bangunan tanah saat ini mencapai 4 - 6 meter, dengan tinggi tidak lebih dari 1 meter. Berdasarkan sisa bangunan yang ada, benteng tersebut memanjang dari arah timur-barat. Bagian tengah benteng terputus, karena tepat pada bangunan ini digunakan sebagai pintu masuk ke halaman rumah penduduk. Menurut masyarakat, tempat ini merupakan Pabean pada masa lalu, tepatnya berada disekitar belokan aliran Sungai Daik. Pengamatan di lapangan menunjukkan di tempat tersebut permukaan tanahnya lebih rendah dan kondisinya berair. Di sekitarnya banyak ditemukan meriam yang saat ini diletakkan di alun-alun. Dua buah meriam yang terdapat di depan Mess Kecamatan memiliki keistimewaan, berbahan tembaga, berukuran panjang 3,35 $\mathrm{m}$. Di bagian atas terdapat hiasan dan pertulisan / 8 / $-O$. 
Heri Sunandar \& Husni Tamrin, Aspek Sosio Politis Naskah Dan Arkeologis

Beberapa meriam yang saat ini berada di sekitar alun-alun menurut informasi ditemukan di sekitar Pabean. Bahkan beberapa buah meriam saat dilakukan penelitian tergeletak di halaman depan rumah penduduk. Meriammeriam tersebut saat ini diletakkan di sekitar alun-alun, menghadap jalan. Dua buah meriam yang berada di depan Mess Pemda, apabila ditilik dari bentuk, ukuran, dan bahan bakunya tampaknya sangat spesifik. Pada masa Kesultanan Riau Lingga kedua meriam itu selain untuk mendukung pertahanan juga digunakan untuk hal-hal bersifat khusus, misalnya sebagai tanda penobatan raja, upacara penyambutan tamu kehormatan, atau untuk upacara pemakaman raja. Lombard menyatakan bahwa meriam-meriam seperti itu pada masanya dianggap sebagai jimat jenis baru, terutama untuk menampakkan kewibawaan raja.

Secara administratif Pulau Mepar termasuk dalam wilayah Desa Mepar, Kecamatan Lingga, berjarak sekitar $1 \mathrm{~km}$ dari Tanjung Butun. Untuk mencapai pulau ini ditempuh dengan menggunakan sampan dengan waktu tempuh sekitar 15 menit. Pulau tersebut saat ini dimanfaatkan masyarakat sebagai pemukiman dengan pusat aktivitasnya di sekitar dermaga. Di Pulau ini terdapat 5 buah bangunan tanah dan beberapa buah meriam yang saat ini terletak di sekitar perkampungan penduduk.

Tiga buah bangunan benteng terletak di selatan pulau, satu di sebelah barat, dan sisanya berada di utara. Benteng I terletak di atas bukit, sebelah tenggara pulau. Benteng tersebut dibangun dari tanah yang dikeraskan, terlihat dari susunan tanah dan kerikil. Benteng tanah ini berukuran $25 \mathrm{~m} \mathrm{X}$ $23 \mathrm{~m}$, tebal dinding antara 2,5 - 3 meter dan tinggi antara $1-1,5$ meter. Benteng ini dikelilingi oleh parit yang cukup dalam, di bagian pintu masuknya terdapat saluran yang kemungkinan digunakan untuk mengeluarkan air dari dalam benteng.

Benteng I menghadap ke baratlaut, di sudut timurlaut dan utara terdapat kelebihan tanah (tonjolan) berukuran $2-3$ meter, menyerupai bastion. Benteng terletak di tempat lebih tinggi, sehingga memudahkan pengawasan daerah sekitarnya. Melalui benteng I ini dapat diawasi Pulau Lingga yang berada di sebelah utaranya, dan Pulau Kolombok di sebelah selatan.

Benteng II dalam kondisi rusak, berdenah persegi empat, berjarak sekitar 5 meter dari garis pantai dan berada pada ketinggian 3 meter diatas permukaan laut. Benteng seluas sekitar $300 \mathrm{~m} 2$ ini, terletak di sebelah selatan pulau. Melalui benteng ini tampak Pulau Kolombok yang berada di sebelah selatannya.

Benteng III terletak di Kampung Hulu, berjarak sekitar 200 meter di sebelah baratdaya benteng II. Bangunan ini berjarak sekitar 20 meter dari garis pantai, dengan ketinggian sekitar 6 meter diatas permukaan laut. Bangunan ini berbentuk segitiga dengan luas sekitar $150 \mathrm{~m} 2$. 
Al-Fikra: Jurnal IImiah Keislaman, Vol.14, No.2, Juli - Desember 2015

Benteng IV terletak di kampung yang sama dengan benteng III, dengan jarak sekitar 200 meter dari benteng III. Benteng ini berbentuk persegi empat berukuran luas sekitar $300 \mathrm{~m} 2$, sedangkan benteng $\mathrm{V}$ terletak di kampung yang sama, berjarak sekitar 200 meter dari benteng IV, berbentuk persegi empat. Kondisi benteng-benteng tersebut saat ini rusak dan dipenuhi dengan tanaman liar.

\section{Benteng Pertahanan Kerajaan Lingga}

Menilik bentuk, bahan, dan pola hias meriam yang terdapat di benteng Bukit Cening dengan yang ada di Pulau Mepar menunjukkan bahwa meriammeriam yang terdapat di Pulau Lingga memiliki kualitas yang lebih baik dibandingkan dengan yang terdapat di Pulau Mepar. Meriam yang terdapat di Lingga menggunakan bahan yang lebih baik dan memiliki tanda-tanda khusus yang menunjukan bahwa meriam tersebut didatangkan dari Belanda, diketahui dari beberapa pertulisan seperti VOC, HB, X, O dan lain-lain. Sebaliknya pada meriam yang terdapat di Pulau Mepar berbahan kurang baik dan tidak terdapat pertulisan ataupun tanda-tanda lain. Kualitas bahan yang kurang baik mengakibatkan salah satu meriam yang terdapat di Pulau Mepar pecah pada bagian ujungnya akibat panas karena terlalu sering digunakan. Bila dibandingkan dengan yang terdapat di Bukit Cening, meriam di Pulau Mepar lebih kasar, kemungkinan meriam tersebut buatan lokal atau didatangkan dari daerah yang belum maju teknologi pembuatannya.

Menilik angka tahun yang terdapat pada meriam yang terdapat di Bukit Cening kemungkinan meriam itu lebih tua dibandingkan dengan yang ada di Mepar. Pertulisan angka tahun 1783 dan 1797 sejaman dengan pindahnya pusat kota Kerajaan Melayu-Riau ke Lingga. Sedangkan informasi mengenai keberadaan meriam di Pulau Mepar adalah saat diangkutnya perlengkapan perang Kesultanan Melayu dari Pulau Mepar ke Reteh pada tahun 1858, diantara peralatan perang itu adalah meriam-meriam (Abrus,1998:56). Mungkin pada waktu itu meriam-meriam tersebut dalam kondisi baru, sekitar 40-70 tahun lebih baru dibandingkan meriam-meriam VOC.

Apabila dilihat dari kondisi, bahan maupun pola hias meriam yang terdapat di Bukit Cening, Pabean, serta beberapa yang ditemukan tercecer di Pulau Lingga sebagian besar memiliki persamaan. Dengan demikian kemungkinan masa pembangunan benteng Bukit Cening, Pabean, dan Kuala Daik sejaman. Sedangkan apabila dibandingkan dengan meriam yang terdapat di Pulau Mepar, kemungkinan masa pembangunannya lebih belakangan, tidak berselang jauh dengan penggunaan meriamnya pada saat pertama digunakan.

\section{Eksistensi BentengB agi Kesultanan Lingga}


Heri Sunandar \& Husni Tamrin, Aspek Sosio Politis Naskah Dan Arkeologis

Bentuk dan ukuran benteng tanah di Kerajaan Lingga tidak sebesar atau seluas bangunan benteng yang banyak kita jumpai. Benteng tanah ini lebih tepat disebut sebagai pos-pos pertahanan. Pertahanan keamanan lebih banyak didukung oleh pos-pos, yang merupakan bagian dari suatu sistem pertahanan keamanan pada waktu itu. Pos-pos keamanan ini dirancang untuk saling dukung-mendukung menjaga akses masuk ke pusat kota kerajaan. Kapal-kapal yang akan mencapai Pulau Lingga umumnya berlayar melalui sebelah barat pulau, karena merupakan jalur perdagangan yang ramai, sehingga menjadikan jalur tersebut aman dari perompak. Penyebab lainnya adalah karena jarak pencapaianya lebih dekat dengan ombak tidak seganas Laut China Selatan.

Benteng IV dan III merupakan lapis pertama pertahanan bagi kapal yang menuju ke pusat Kerajaan Lingga melalui Tanjung Butun. Disusul kemudian oleh pertahanan benteng $\mathrm{V}$ dan benteng I. Sedangkan bagi kapal yang memilih mengelilingi Pulau Mepar, Benteng III merupakan lapis pertama pertahanan, disusul benteng ke II dan benteng I. Tampaknya Benteng I dan III memiliki peran yang cukup penting mengingat fungsi benteng ini menjaga beberapa sisi pulau. Benteng III didesain berbentuk segitiga untuk menjaga sisi barat dan selatan, sedangkan benteng I berfungsi untuk menjaga 3 sisi yaitu sebelah utara, selatan dan timur Pulau. Keletakan benteng tersebut pada tempat yang tinggi menjadikan benteng I mampu mengawasi beberapa sudut, sehingga tumpuan pertahanan keamanan benteng Pulau Mepar terletak pada benteng I. Melalui benteng I tembakan dapat diarahkan ke Tanjung Butun atau ke Selat Kolombok (lihat peta). Tonjolan tanah di sisi utara dan timur yang menyerupai bastion kemungkinan berfungsi untuk meletakkan meriam khusus, berukuran lebih besar. Sudut-sudut tersebut dilengkapi meriam yang diarahkan ke Tanjung Butun atau ke arah kapal yang melintas Selat Kolombok.

Fungsi pertahanan benteng I didukung juga dengan benteng Bukit Cening, yaitu mengantisipasi kapal-kapal yang lolos dari Benteng Pulau Mepar untuk mendekati Kuala Daik. Meriam-meriam yang saat ini terdapat di Bukit Cening menurut informasi ditemukan juga di areal antara Bukit Cening dan Kuala Daik. Apabila kapal telah sampai didepan pintu masuk (Kuala Daik) maka pertahanan dilakukan oleh pos-pos di Kuala Daik. Dan apabila berhasil lolos pertahanan/penyerangan dilakukan dengan meriam-meriam yang ada di sepanjang tepi Sungai Daik. Menurut informasi beberapa meriam yang saat ini terdapat di kantor polisi dan lain-lain diangkat dari pinggiran Sungai Daik. Bahkan beberapa meriam sampai saat ini masih ada yang belum terangkat dari dasar sungai.

Pertahanan terakhir kemungkinan adalah benteng tanah yang terdapat di Pabean. Beberapa meriam yang saat ini berada di sekitar alun-alun menurut informasi ditemukan di sekitar Pabean. Dua buah meriam yang berada di depan Mess Pemda, apabila ditilik dari bentuk, ukuran, dan bahan 
Al-Fikra: Jurnal IImiah Keislaman, Vol.14, No.2, Juli - Desember 2015

bakunya tampaknya sangat spesifik. Pada masa Kesultanan Riau Lingga kedua meriam itu selain untuk mendukung pertahanan juga digunakan untuk hal-hal bersifat khusus, misalnya sebagai tanda penobatan raja, upacara penyambutan tamu kehormatan, atau untuk upacara pemakaman raja.

Sejarah mencatat bahwa kekuasaan para sultan pada akhirnya berada di bawah dominasi Belanda. Perdagangan yang menjadi tulang punggung perekonomian kerajaan dan hasil-hasil perdagangan yang dilakukan daerahdaerah pada akhirnya harus dijual pada Belanda dengan harga yang telah ditentukan, terutama barang-barang yang bernilai tinggi di pasaran dunia. Para sultan dipaksa menandatangani perjanjian-perjanjian yang memberatkan. Setiap pergantian sultan merupakan suatu kesempatan baru bagi Belanda untuk mengadakan dan memperbaharui perjanjian dengan ikatan-ikatan yang lebih berat. Hal inilah yang mengakibatkan beberapa sultan membangkang.

Tampaknya sistem pertahanan keamanan yang terdapat di Kerajaan Lingga merupakan suatu sistem pertahanan semu. Pertahanan keamanan hanya dipakai oleh kerajaan apabila kedatangan "musuh", yaitu perompak yang mengganggu perdagangan Belanda, karena pada hakekatnya saat itu sesama Bangsa Melayu merasa memiliki beban yang sama, yaitu mematahkan dominasi Belanda atas jalur-jalur perdagangan di Selat Malaka. Salah satu contoh adalah sikap mendua pasukan dari Kerajaan Lingga yang diperintahkan menyerang Reteh. Pasukan Kesultanan Riau-Lingga yang tergabung dengan pasukan Belanda melakukan penyerangan ke Reteh tidak dengan sepenuh hati, sehingga Belanda terpaksa meminta tambahan pasukan untuk mengganti posisi orang-orang Melayu tersebut.

Penempatan benteng-benteng pertahanan di beberapa kerajaan pada masa itu sedikit banyak untuk kepentingan Belanda. Peralatan perang yang didatangkan dari Belanda merupakan salah satu petunjuk bahwa pembelian persenjataan untuk pertahanan keamanan dengan sepengetahuan dan dikontrol oleh Belanda. Sedangkan salah satu bentuk pengawasan terhadap penggunaannya dilakukan dengan menempatkan sepasukan kecil di Pulau tersebut.

Pada masa pemerintahan Sultan Said Mudoyatsyah harus membayar mahal kemenangannya berperang dengan Raja Muda Jumahat yang dibantu Belanda dengan menanda tangani kontrak politik yang dikenal dengan Traktaat Van Vrede en Vriendshap salah satu isinya adalah mengakui hak Pemerintah Hindia Belanda untuk mendirikan benteng-benteng di Indragiri guna melindungi pelayaran, perdagangan, dan pencegahan perampokan laut.

Berdasarkan beberapa hal, seperti tersebut di atas, penempatan bangunan-bangunan pertahanan merupakan sebuah sistem pertahanan yang digunakan Belanda untuk membatasi gerak seorang penguasa (sultan). Bangunan pertahanan digunakan untuk mengurung sultan di dalam kota 
Heri Sunandar \& Husni Tamrin, Aspek Sosio Politis Naskah Dan Arkeologis

kerajaannya. Penggunaan meriam ataupun peralatan-peralatan perang diawasi oleh Belanda. Salah satu isi perjanjian yang ditanda tangani oleh Sultan Mahmud Muzafar Syah tanggal 10 Juni 1837 adalah: Belanda akan menempatkan suatu pasukan kecil di Lingga. Pengaturan seperti itu adalah untuk kepentingan keamanan pemerintahan Belanda. Wujud dominasi ini diketahui dari beberapa keputusan Belanda untuk mencopot beberapa sultan yang dianggap membangkang.

\section{KESIMPULAN}

Kesultanan Riau Lingga bermula dari Tanah Bintan yaitu di Kotalama / Kota piring Tanjung Pinang. Setelah kondisi politik yang tidak kondusif , maka Sultan Mahmud memindahkan pusat pemerintahan ke Lingga (Daik). Namun setelah Sultan Mahmud wafat, situasi politik interen kesultanan semakin tidak harmonis karena campur tangan politik adudomba yang dilakukan oleh penjajah Belanda dan Inggris, disamping ambisi pribadi dikalangan bangsawan Melayu dan Bugis yang haus kekuasaan menjadikan kesultanan Melayu ini dibagi tidak bisa bertahan lama. Pada tahun 1911 kesultanan ini terpaksa harus dibubarkan Belanda karena tidak mau menanda tangani surat perjanjian dengan penjajah Belanda. Selanjutnya semua pemerintahan langsung di bawah residen Belanda yang berpusat di Tanjung Pinang.

Jika dipelajari sejarah kesultanan melayu Riau Lingga akan tampak keterkaitan kesultanan ini dengan kesultanan Malaka, Johor, Trenggano, Pahang, Singapura, Siak, Indragiri dan Aceh. Banyak situs-situs sejarah yang masih wujud dan seyogianya dapat dilestarikan dengan sungguh-sunggu disamping sebagai bukti kejayaan kesultanan Melayu Nusantara, sekaligus juga sebagai objek wisata sejarah, budaya, seni dan lain-lain. Masih banyak lagi situs-situs sejarah yang belum dapat diungkapkan dengan jelas dan terperinci tentang bentuk dan realitasnya pada masa lalu, karena kekurangan informasi tentang masalah tersebut.

Rekomendasi

Diharapkan kajian penelitian ini dapat dilakukan dengan mengadakan penelitian lainnya yang berhubungan dengan kesultanan Melayu Riau Lingga, misalnya kajian naskah, kajian seni dan budaya, dan lain-lain.

Pemerintah Daerah Kabupaten / Kota maupun Propinsi dan Pusat seyogianya memberikan perhatian yang serius untuk melestarikan semua peninggalan sejarah kesultanan dan lain-lain yang masih ada dengan membuat segala pasilitas baik yang berhubungan dengan pelestarian budaya dan situs sejarah, termasuk juga media transportasi untuk menuju tempat wisata sejarah dan wisata budaya serta lainnya. Karena ini semua dapat mengangkatkan penghargaan dan nama baik suatu bangsa dan negara, serta pendapatan yang diperoleh dari wisatawan domistik maupun manca negara. 
Al-Fikra: Jurnal IImiah Keislaman, Vol.14, No.2, Juli - Desember 2015

\section{DAFTAR PUSTAKA}

Bakar Abu dan Abdul Latif. 1997. S ejarah di Selat Melaka. Malaka: PSMCM. Ahmad, A. Samad. 1985. Kerajaan J ohor Riau. Selangor: Safeguarda.

Haji, Raja Ali. 2002. Tuhfat al-Nafis-Sejarah Riau Lingga dan Daerah Takluknya 1699-1864. Kepulauan Riau: Dinas Pariwisata Kepri.

Haji, Raja Ali. Gurindam Dua Belas.

Husein, Tengku, dkk., Mengenal dan Mengenang Kebesaran Kerajaan Lingga Riau Sebagai Pusat Kebudayaan Melayu, Lingga, Pemda Lingga, 2007.

Djama, Irman. Mengisi Roh Ke Dalam J asad-Upaya Memaknai Pesan AyatAyat Gurindam Dua belas Raja Ali Haji Sebagai Ideologi Untuk Menggugat Semangat Zaman, Yogyakarta, Navila, 2007.

Kadir, Daud. , H.M.A. Effendi, dkk. Sejarah Kebesaran Sultan Lingga-Riau, Lingga, Pemda Lingga, 2007.

Kasmadi dan Isma Maulana, Lingga Bunda Tanah Melayu, Pekanbaru, Alaf Riau, 2007.

Putra, Lukmanulhakim, Pulau Penyengat Nyata-nya Inderasakti, Bandung, Rijakarsa Mandiri, 2006.

Razak, Abdul. Patahnya Gunung Daik, Pekanbaru, Mulia Indah Kemala, 2010.

Sofyan, Asyim, dkk. Bentan "The Spirit of Malay" dan sisa Peninggalannya, Kepri, Khazanah Bentan, 2011.

Yunus, Hamzah. Peninggalan-Peninggalan Sejarah di Pulau Penyengat, Tanjung Pinang, Unri Press, 2003.

Yacob, M. Amin. Sejarah Kerajaan Lingga, Pekanbaru, Unri Press, 2009.

Yusuf, Ahmad, Anwar Syair, dkk, Dari Kesultanan Melayu J ohor riau ke Kesultanan Melayu Lingga-Riau, Pekanbaru, Pemda Provinsi Riau, 1993.

Yunus, Hasan. Raja Ali Haji Budayawan Gerbang Abad XX, Pekanbaru, Unri Press, 1988.

Yunus Hasan, Penyengat Indera Sakti, Kepri, Lembaga Kesultanan Riau Lingga, tt. 